\title{
Effects of Synthetic Neural Adhesion Molecule Mimetic Peptides and Related Proteins on the Cardiomyogenic Differentiation of Mouse Embryonic Stem Cells
}

\author{
Ruodan Xua Sureshkumar Perumal Srinivasan ${ }^{\mathrm{b}}$ Poornima Sureshkumar ${ }^{\mathrm{b}}$ \\ Erastus Nembu Nembo ${ }^{b}$ Christoph Schäfer ${ }^{b}$ Judith Semmler ${ }^{b}$ Matthias Matzkies ${ }^{b}$ \\ Morten Albrechtsen ${ }^{a}$ Jürgen Hescheler ${ }^{b}$ Filomain Nguemo ${ }^{b}$
}

aENKAM Pharmaceuticals A/S, Copenhagen, Denmark, 'bInstitute of Neurophysiology, Center for Physiology and Pathophysiology, Medical School University of Cologne, Cologne, Germany, ${ }^{\circ}$ Current addresses: Interdisciplinary Nanoscience Center (iNANO), Aarhus University, Aarhus C, Denmark

\section{Key Words}

Embryonic stem cells • Bioactive peptides • NCAM • Differentiation • Cardiomyocyte

\begin{abstract}
Background/Aims: Pluripotent stem cells differentiating into cardiomyocyte-like cells in an appropriate cellular environment have attracted significant attention, given the potential use of such cells for regenerative medicine. However, the precise mechanisms of lineage specification of pluripotent stem cells are still largely to be explored. Identifying the role of various small synthetic peptides involved in cardiomyogenesis may provide new insights into pathways promoting cardiomyogenesis. Methods: In the present study, using a transgenic murine embryonic stem (ES) cell lineage expressing enhanced green fluorescent protein (EGFP) under the control of $\alpha$-myosin heavy chain $(\alpha-M H C)$ promoter (paMHC-EGFP), we investigated the cardiomyogenic effects of 7 synthetic peptides (Betrofin3, FGLs, FGL, hNgf_C2, EnkaminE, Plannexin and (3) on cardiac differentiation. The expression of several cardiac-specific markers was determined by RT-PCR whereas the structural and functional properties of derived cardiomyocytes were examined by immunofluorescence and electrophysiology, respectively. Results: The results revealed that Betrofin3, an agonist of brain derived neurotrophic factor (BDNF) peptide exerted the most striking pro-cardiomyogenic effect on ES cells. We found that BDNF receptor, TrkB expression was up-regulated during differentiation. Treatment of differentiating cells with Betrofin3 between days 3 and 5 enhanced the expression of cardiacspecific markers and improved cardiomyocyte differentiation and functionality as revealed by genes regulation, flow cytometry and patch clamp analysis. Thus Betrofin3 may exert its cardiomyogenic effects on ES cells via TrkB receptor. Conclusion: Taken together, the results
\end{abstract}

Filomain Nguemo

KARGER 125
Institute for Neurophysiology, University of Cologne

Robert-Koch-Str. 39, 50931 Cologne (Germany)

Tel. +49-221-478-6940, Fax +49-221-478-3834, E-Mail filo.nguemo@uni-koeln.de 


\section{Cellular Physiology Cell Physiol Biochem 2015;35:2437-2450

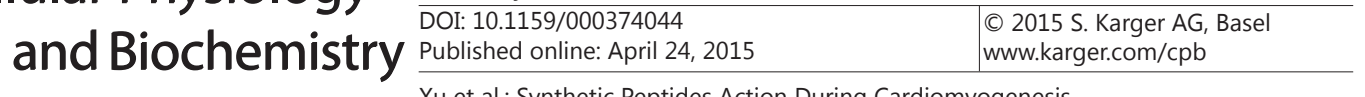

suggest that Betrofin3 modulates BDNF signaling with positive cardiomyogenic effect in stage and dose-dependent manner providing an effective strategy to increase ES cell-based generation of cardiomyocytes and offer a novel therapeutic approach to cardiac pathologies where BDNF levels are impaired.

Copyright (C) 2015 S. Karger AG, Basel

\section{Introduction}

Cardiac diseases, causing severe loss of terminally differentiated cardiomyocytes and eventually leading to heart failure, are considered to be a major cause of death worldwide [1]. Most cardiomyopathies at the stage of heart failure are characterized by a significant loss of functioning cardiomyocytes. Adult mammals do not sufficiently regenerate cells to compensate for lost cardiomyocytes. Cardiac transplantation is the only choice for end-stage heart failure, but the insufficient numbers of available donor organs limits this option. The development of new therapeutic approaches for heart failure and alternative therapies has therefore become indispensable although many hurdles remain to be solved before these developments can be translated to the clinic [2-4]. Amongst the different regenerative approaches analyzed, cardiac cell therapy has gained wide acceptance with pluripotent stem cells as a potential cell source. In vitro analysis using both ES cells and induced pluripotent stem (iPS) cells is currently the mainstream research to evaluate their efficiency in cardiac cell therapy. Similar to in vivo process during normal mammalian development, both mouse and human ES cell lines can differentiate and give rise to derivatives of all three primary germ layers, including functional cardiomyocytes [5], depending on the cultivation conditions [6]. During differentiation, cardiac-specific proteins, receptors, and ion channels are expressed in a developmental stage-dependent manner, which nearly recapitulates the developmental pattern of early cardiomyogenesis [7]. However, directing their differentiation towards cardiac lineage is quite challenging. Multiple in vitro differentiation techniques are currently used with limited success to induce high efficiency of pure functional cardiomyocytes derived from pluripotent (ES and iPS) cells from different developmental niches [8]. Efficient differentiation of pluripotent stem cells into cardiomyocytes, that are viable suitable for transplantation, may therefore lead to widespread future applications in biomedical and clinical research. Moreover, the established protocols for pluripotent stem cells differentiation require adjustment to match the time line of human heart development [9]. Early cardiomyogenesis is regulated by both endogenous and exogenous factors such as the transforming growth factor- $\beta$ superfamily, bone morphogenetic proteins (BMPs), FGFs, and different members of the Wnt/wingles (WNT) signaling family as well as retinoic acid [6, 10-13]. A number of studies showed the importance for FGF signaling in regulating cardiac cell proliferation and differentiation [6]. The role of FGFs is further emphasized by the observation that mutations in some FGF receptors (FGFR) are associated with human congenital diseases $[11,14]$. The FGFR, however can also be activated by neural cell adhesion molecule (NCAM), L1-CAM, N-cadherin [15] and small synthetic polypeptide ligands [16]. Brain-derived neurotrophic factor (BDNF) is critically involved in modeling the developing nervous system and is an important regulator of a variety of crucial functions in the mature central nervous system [17]. Although found in the adult heart, BDNF has been shown to express only in coronary artery and capillary endothelial cells. BDNF binds to the TrkB receptor, which is expressed by endothelial cells and smooth muscle cells, initiates receptor dimerization, autophosphorylation, and subsequent intracellular signaling [17]. But the role and functional significance of this protein in cardiac cells remain an unfolding story.

The NCAM, a prominent cell surface glycoprotein of the vertebrate nervous system was first reported to be significantly expressed in the developing heart [18]. A number of studies carried out on different animal embryonic models indicate numerous variants of the protein being expressed in diverse loci of the developing heart. Studies also indicate that the expression of these NCAM variants also changes with each developmental stage of the heart [18-23]. Even though these studies point out the involvement of NCAM and its different 


\section{Cellular Physiology Cell Physiol Biochem 2015;35:2437-2450 \begin{tabular}{ll|l} 
and Biochemistry & $\begin{array}{l}\text { DOI: 10.1159/000374044 } \\
\text { Published online: April 24, } 2015\end{array}$ & $\begin{array}{l}\text { ○ 2015 S. Karger AG, Basel } \\
\text { www.karger.com/cpb }\end{array}$ \\
\hline
\end{tabular} Xu et al.: Synthetic Peptides Action During Cardiomyogenesis}

variants in cardiogenesis, none has explored the possible applicability of synthetic NCAM peptides in inducing cardiac differentiation in ES cells in vitro.

In this study we have evaluated the efficiency of several peptides which were designed based on NCAM (C3, Plannexin) and related proteins such as BDNF (Betrofin3) and growth factors sequences ( $\mathrm{FGL}_{\mathrm{L}}, \mathrm{FGLs}$, EnkaminE and hNgf_C2) in inducing cardiac differentiation. Our data indicate that the presence of Betrofin3 during cardiac differentiation leads to a significant increase in the expression of cardiac progenitor and cardiomyocyte markers, at least in part via activation of TrkB receptors, thereby indicating involvement of BDNF in process of cardiogenesis. Although there is room for improvement, our differentiation method produces safe, functional cardiomyocytes and may provide a practical way to use small peptides for cell-based therapy of heart diseases.

\section{Materials and Methods}

\section{Peptides}

All peptides were purchased from Peptides\&Elephants (Potsdam, Germany) and the corresponding bioactive counterparts were synthesized by employing the Fmoc-protected amino acids on TentaGel resin. The peptides were synthesized in two forms: a) dimeric peptides composed of two peptide monomers linked through their N-terminal ends by iminodiacetic acid: FGLs (VAENQQGKSKA), and FGLL (EVYVVAENQQGKSKA) [23]; b) tetrameric dendrimers composed of four monomers coupled to a lysine backbone: Betrofin3 (RGIDKRHWNSQ), EnkaminE (TIMGLKPETRYAVR), Plannexin (DVRRGIKKTD), C3 (ASKKPKRNIKA), and hNgf_C2 (ETKCRDPNPVDSG) [24-27]. Peptides were at least 85\% pure as estimated by mass spectrometry and analytical high-performance liquid chromatography (HPLC). The peptides were dissolved in MilliQ water and the concentrations of peptides were determined spectrophotometrically by measuring the absorption at $205 \mathrm{~nm}$.

\section{Cell Culture}

We used aPIG44 cells, a derivative of the D3 mouse ES cell line that stably express the EGFP under the control of $\alpha$-myosin heavy chain ( $\alpha$-MHC) promoter to investigate the extent of cardiomyogenesis [28]. ES cells of the stably transfected clone (aPIG44) [29] were cultured on mouse embryonic fibroblasts in high-glucose Iscove's modified Dulbecco's medium (IMDM) supplemented with non-essential amino acids (NEAA, $0.1 \mathrm{mM}$ ), $\beta$-mercaptoethanol (0.1 mM), penicillin-streptomycin (1\%), LIF (ESGR) (500 U/ml), G418 $(0.5 \mathrm{mg} / \mathrm{mL})$, and batch-tested fetal calf serum (FCS) (15\% v/v) (all from Invitrogen, Karlsruhe, Germany). ES cells maintained on feeder cells were dissociated with trypsin/EDTA, then plated onto $0.1 \%$ gelatincoated dishes and incubated at $37^{\circ} \mathrm{C}$. Over the next $90 \mathrm{~min}$, non-adherent cells were re-plated onto $0.1 \%$ gelatin-coated dishes and cultured for further cardiac differentiation. Previous studies revealed that the ES cells lines ( $\alpha$ PIG44 derived from a parental ES cell line D3) used in the study expressed the genes known to be associated with undifferentiated state.

\section{ES Cell Differentiation and peptides screening}

For optimal cardiac differentiation, we used the stage-specific optimization strategy of embryoid body (EBs) formation in 96-well microtiter plates as previously outlined [30, 31]. Briefly, ES cells were trypsinized (day 0), cultured in 96-well round bottom microtiter plates to form EBs. The protocol illustrated in Figure $1 \mathrm{~A}$ was used to generate results in a reproducible and quantitative manner. Briefly, ES cells were transferred into Iscove's modified Dulbecco's Medium (IMDM) with 20\% batch-tested FCS, NEAA, $\beta$-mercaptoethanol and penicillin-streptomycin. Cells (about 700 ES cells) were seeded into round bottom of 96-well culture plates (Fig. 1B) by gravity with $50 \mu \mathrm{l}$ differentiation medium (same as ES cell media minus LIF). The cells, unable to adhere, coalesced to form a large number of uniformly-sized Embryoid Bodies (EBs) (Fig. 1C). Then peptides or FGF (bFGF, FGF8, FGF10) (Life technologies, Carlsbad, CA, USA) or K252a (Sigma-Aldrich, St. Louis, MO, USA) was added into each well of 96 -well plate and incubated at $37^{\circ} \mathrm{C}$ under $5 \% \mathrm{CO}_{2}$ and $95 \%$ humidity. The peptides and growth factors were added with the following sequence: 1) day 0-12 (EP1); 2) day 0-2 (EP2); 3) day 3-5 (EP3) as indicated in Figure 1A as well. EBs were microscopically observed for foci of beating activity from day 8. 


\section{Cellular Physiology Cell Physiol Biochem 2015;35:2437-2450 \begin{tabular}{l|l} 
DOI: 10.1159/000374044 & () 2015 S. Karger AG, Basel
\end{tabular} and Biochemistry Published online: April 24, 2015 www.karger.com/cpb \\ Xu et al.: Synthetic Peptides Action During Cardiomyogenesis}

All EBs were characterized morphologically, by RT-PCR, immunofluorescence, flow cytometry (FC) and examined electro-physiologically at different stages of in vitro differentiation (Fig. 1A).

\section{RNA extraction and RT-PCR}

Cells were harvested on days $0,3,4,7$ and 9 of EB differentiation and stored at $-80^{\circ} \mathrm{C}$ in cell lysis buffer RLT (Qiagen, Hilden, Germany). Three independent samples were collected for each time point studied.

Total RNA was extracted using the RNeasy Mini Kit and amplified by PCR (OneStep RT-PCR kit) according to the manufacturer's instructions (Qiagen). The primer sequences are shown in Table 1. The PCR products were electrophoretically separated on $1.5 \%(\mathrm{w} / \mathrm{v})$ agarose gels containing $1 \%(\mathrm{w} / \mathrm{v})$ ethidium bromide and illuminated with UV light.

\section{Immunofluorescence analysis}

For immunofluorescence, EB outgrowths cultivated on gelatin-coated chamber slides were fixed with $4 \%$ paraformaldehyde (PFA) at room temperature (RT) for $20 \mathrm{~min}$ and then permeabilized

Table 1. Primers used for RT-PCR

\begin{tabular}{|c|c|c|c|c|}
\hline \multirow{3}{*}{$\begin{array}{l}\text { Gene } \\
\text { Brachyury }\end{array}$} & \multicolumn{2}{|c|}{ Primer sequences } & \multirow{3}{*}{$\frac{\operatorname{Tm}\left({ }^{\circ} \mathrm{C}\right)}{66}$} & \multirow{3}{*}{$\begin{array}{l}\text { Size (bp) } \\
320\end{array}$} \\
\hline & Forward & GCTCATCGGAACAGCTCTCCAACC & & \\
\hline & Reverse & GGAGAACCAGAAGACGAGGACGTG & & \\
\hline \multirow[b]{2}{*}{$M l c-2 v$} & Forward & AGCCTTCACAATCATGGACC & \multirow[b]{2}{*}{58} & \multirow[b]{2}{*}{295} \\
\hline & Reverse & ССTCCCTGCTTGTGTGGTCA & & \\
\hline \multirow[b]{2}{*}{ TrkA } & Forward & CGTCATGGCTGCTTTTATGG & \multirow[b]{2}{*}{58} & \multirow[b]{2}{*}{75} \\
\hline & Reverse & ACTGGCGAGAAGGAGACAG & & \\
\hline \multirow[b]{2}{*}{$\operatorname{Trk} B$} & Forward & TTCCGCTAGGATTTGGTGTAC & \multirow[b]{2}{*}{61} & \multirow[b]{2}{*}{494} \\
\hline & Reverse & GAGCAGCCAGACGTGCAGATG & & \\
\hline \multirow[b]{2}{*}{$\operatorname{TrkC}$} & Forward & TGGCTGCCAGGAAGGATTT & \multirow[b]{2}{*}{61} & \multirow[b]{2}{*}{413} \\
\hline & Reverse & GTGTGTCCTCCCACCCTGTA & & \\
\hline \multirow[b]{2}{*}{ p75NTR } & Forward & CCGATACAGTGACCACTGTGATG & \multirow[b]{2}{*}{62} & \multirow[b]{2}{*}{97} \\
\hline & Reverse & AGCAGCCAAGATGGAGCAATAGAC & & \\
\hline \multirow{2}{*}{ Bdnf } & Forward & CTGGAGAGCGTGAATGGGC & \multirow{2}{*}{58} & \multirow[b]{2}{*}{622} \\
\hline & Reverse & ATCTTCCСCTTTTAATGGTC & & \\
\hline \multirow[b]{2}{*}{ Gata4 } & Forward & CTCGATATGTTTGATGACTTCT & \multirow[b]{2}{*}{55} & \multirow[b]{2}{*}{347} \\
\hline & Reverse & CGTTTTCTGGTTTGAATCCC & & \\
\hline \multirow[b]{2}{*}{ Nkx 2.5} & Forward & AGCAACTTCGTGAACTTTG & \multirow[b]{2}{*}{56} & \multirow[b]{2}{*}{345} \\
\hline & Reverse & CCGGTCCTAGTGTGGA & & \\
\hline \multirow[b]{2}{*}{ Fgfr1 } & Forward & GCTGACTCTGGCCTCTACGCT & \multirow[b]{2}{*}{62} & \multirow[b]{2}{*}{648} \\
\hline & Reverse & CAGGATCTGGACATACGGCAA & & \\
\hline & Forward & CTCCTTCAGTTTAGTTGAGGATACCA & & \\
\hline Fgfr 2 & Reverse & GAAGATCCAAGTTTCACTGTCTACCG & 60 & 292 \\
\hline & Forward & GAAGAATGGCAAAGAATTCCGAG & & \\
\hline Fgfr 3 & Reverse & ССTCTAGCTCCTTGTCGGTGG & 60 & 401 \\
\hline & Forward & GAACTCTCTGGGTAGCATTCGCT & & \\
\hline Fgfr 4 & Reverse & TGTCTGTTGTCTTGAGGACTTGTACG & 58 & 248 \\
\hline & Forward & СТСССТGССТССАAССАТСATC & & \\
\hline Ncam & Reverse & TCTCGTCATCTTCCTCCTCGTTCTC & 64 & 359 \\
\hline & Forward & GTGTTCCTACCCCCAATGTG & & \\
\hline Gapdh & Reverse & CTTGCTCAGTGTCCTTGCTG & 60 & 349 \\
\hline
\end{tabular}
with $0.2 \%$ Triton X-100 in PBS. After blocking with 3\% BSA in PBS, cells were incubated with the primary anti-cardiac Troponin T (ab10214, Abcam, Cambridge, England) in 1:400 dilutions over night at $4^{\circ} \mathrm{C}$. Thereafter, cells were washed three times with PBS and incubated with AlexaFluor-555-conjugated donkey anti-mouse secondary antibody (Molecular Probes Inc, Eugene, OR, USA) (1:1000 diluted in 1\% BSA in PBS) and $5 \mu \mathrm{g} / \mathrm{ml}$ Hoechst 33342 in PBS. Immunostaining images were obtained using an Axiovert 200 microscope equipped with a DFW-X710 Sony color digital camera (Sony Berlin, Germany) and Axiovision 4.3 software (Carl Zeiss, Jena, Germany).

Flow cytometry

For flow cytometric (FC) analysis, EBs were washed twice in PBS and dissociated to single cell suspensions with trypsin/EDTA solution for $20 \mathrm{~min}$. Following a washout step with 10\% FBS/DMEM, cells were permeabilized with $0.05 \%$ Triton X-100/PBS buffer for 20 min on ice. After additional washes in PBS, cells were re-suspended in $400 \mu \mathrm{lPBS}$ and kept at $4^{\circ} \mathrm{C}$ until analysis. Cell sorting was performed on FACSAria (BD Biosciences) with the Aria Cell Sorter (BD Biosciences) instrument.

Selective inhibition of TrkB

K252a (Sigma-Aldrich, Missouri USA), a selective inhibitor of tyrosine protein kinase activity of TrkB was dissolved in DMSO at a concentration of $1 \mathrm{mg} / \mathrm{ml}$ and was stored in small aliquots in a freezer. On the day of the experiment, the aliquots were diluted with medium to obtain a final concentration of $30 \mathrm{nM}$. The control vehicle for K252a was 0.1\% DMSO-medium.

\section{Electrophysiological Recording}

After differentiation, the EBs were attached to $3 \mathrm{~cm}$ dish and incubated on a custom-made heating plate $\left(37^{\circ} \mathrm{C}\right)$. Sharp electrode measurements were performed with microelectrodes $(20-40 \mathrm{M} \Omega$ when filled with $3 \mathrm{M} \mathrm{KCl}$ ) made of filament like borosilicate glass capillaries (WPI, Sarasota, FL, USA). Signals were amplified with a SEC-10LX amplifier (Npi electronic, Tamm, Germany) and acquired with the Pulse software (HEKA, Lambrecht, Germany). Data were analyzed offline with the Mini Analysis program (Synaptosoft, Fort Lee, USA). To investigate the immediate effects of peptides, $10 \mu \mathrm{M}$ Betrofin3, $50 \mathrm{ng} / \mathrm{ml} \mathrm{FGF8} \mathrm{or} 100 \mathrm{ng} / \mathrm{ml}$ FGF10 were added to the control differentiated EBs. 


\section{Cellular Physiology Cell Physiol Biochem 2015;35:2437-2450 \begin{tabular}{ll|l} 
and Biochemistry & $\begin{array}{l}\text { DOI: 10.1159/000374044 } \\
\text { Published online: April 24, } 2015\end{array}$ & $\begin{array}{l}\text { ○ 2015 S. Karger AG, Basel } \\
\text { www.karger.com/cpb }\end{array}$ \\
\hline
\end{tabular}}

A Differentiation (Days)

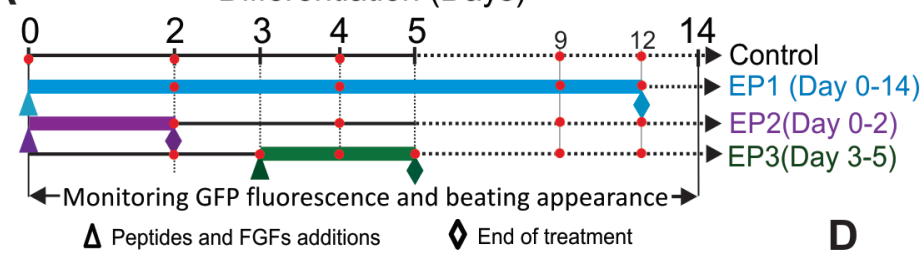

B $\triangle$ Peptides and FGFs additions $\quad \Delta$ End of treatment
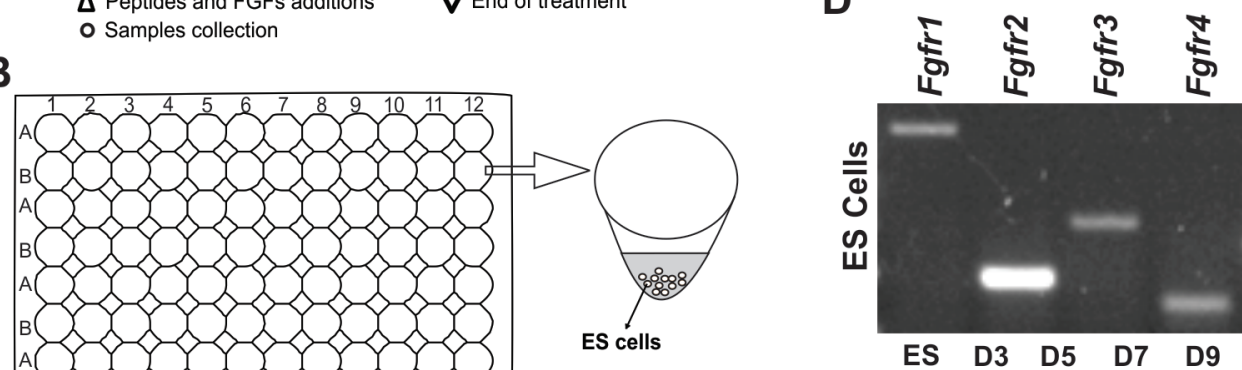

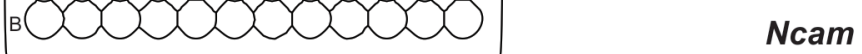

C

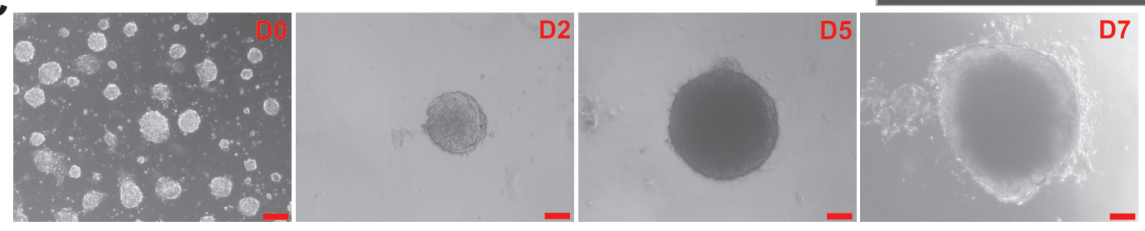

Gapdh $-\cdots$

D7

Fig. 1. Experimental scheme for inducing the cardiomyogenic lineage in ES cells. (A) In order to identify a peptide with highest cardiogenic efficiency and the most effective time frame for peptide application, the peptides were tested on three different time frames i) the differentiation period from D0 to D12 (EP1), ii) D0 to D2 (EP2), and iii) D3 to D5 (EP3). (B) 96-well round bottom plate used for EBs formation. Medium was replaced with fresh medium and test compounds every two days. During differentiation, samples were collected for further experiments. (C) Undifferentiated mouse ES cells (D0) cultured in maintenance medium in the presence of LIF and EBs at D2, D5 and D7 of differentiation, respectively (Scale bars $200 \mu \mathrm{m}$ ). (D) Expression of Fgfrs (Fgfr1, Fgfr2, Fgfr3 and Fgfr4) in undifferentiated ES cells (above panel) and Ncam receptors in EBs at D3, D5, D7, D9 of differentiation (below panel). EP (Experimental Protocol).

\section{Statistical Analysis}

All values are expressed as mean \pm standard error of the mean (SEM) of at least three independent experiments, if not indicated otherwise. Comparison of means was conducted using one-way analysis of variance (ANOVA) or t-test using Prism 5 software (GraphPad Software, San Diego, CA), results were considered statistically significant if the $\mathrm{P}$ value was $<0.05$.

\section{Results}

Verification for the presence of Fgfrs and Ncam expression on ES cells and during differentiation

EB formation from dissociated ES cells was tested using non-adhesive 96-well plates. As preliminary, the effect of ES cells seeding density on EB formation was tested over the range of 500 to $1000 \mathrm{ES}$ cells per well. The minimum input cell number per 96 -well required to form an EB that is able to maintain structural integrity in suspension culture was approximately 700 (Fig. 1B and 1C). To start the experiment, it was important to demonstrate that EBs are able to derive representative developmental germ layers and express pluripotent genes. The presence of markers associated with each of the three germ layers such as $A f p$ (for endoderm), Sox-1 (for ectoderm), and Brachyury (for mesoderm) was confirmed (data not shown). We further checked whether the EBs expressed Fgfrs and Ncam. Thus, RT-PCR analysis of ES cells and EBs during differentiation was performed. The results revealed that 


\section{Cellular Physiology Cell Physiol Biochem 2015;35:2437-2450 \begin{tabular}{ll|l} 
and Biochemistry & $\begin{array}{l}\text { DOI: 10.1159/000374044 } \\
\text { Published online: April 24, } 2015\end{array}$ & $\begin{array}{l}\text { ○ 2015 S. Karger AG, Basel } \\
\text { www.karger.com/cpb }\end{array}$ \\
\hline
\end{tabular} Xu et al.: Synthetic Peptides Action During Cardiomyogenesis}

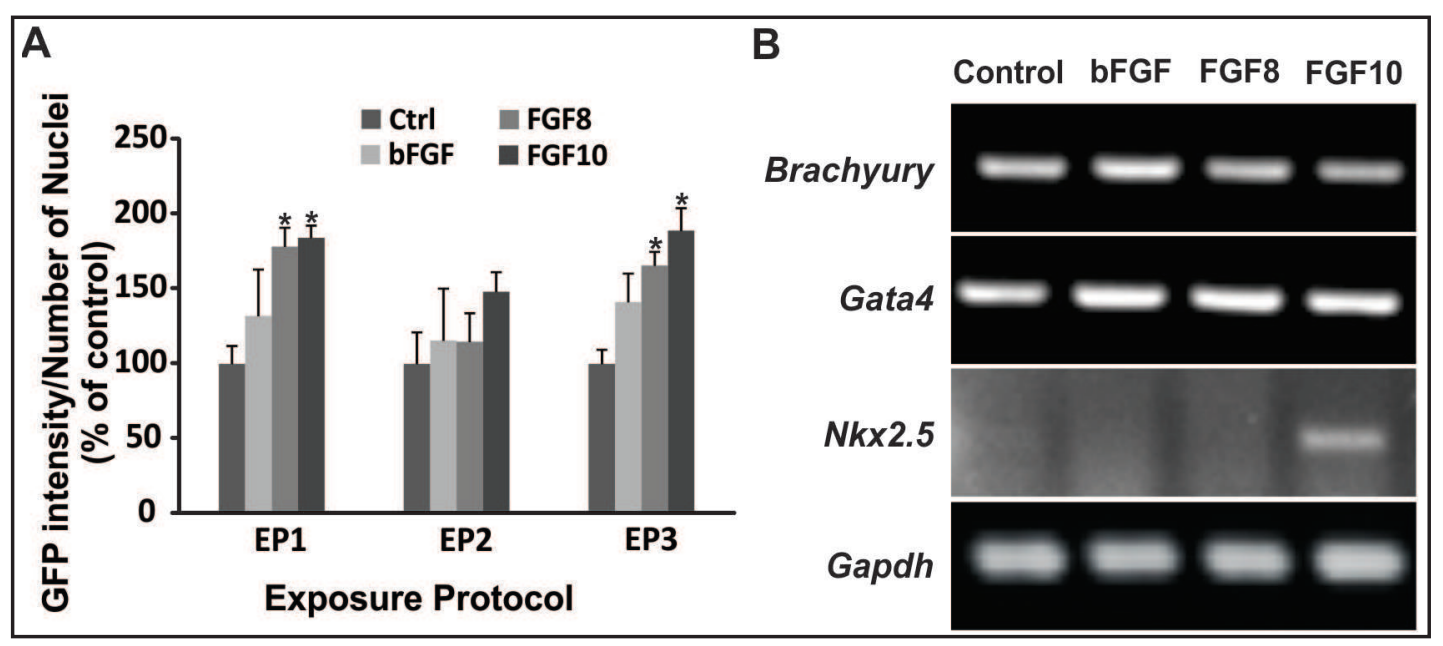

Fig. 2. Fibroblast growth factors- bFGF, FGF8 and FGF10 effect on cardiomyogenesis. (A) Percentage of EGFP positive cells derived from ES cells under FGFs-treatment following EP1, EP2, EP3 protocol. EBs were dissociated and cells quantified at day 12 of differentiation. Results are reported as the mean \pm SD $(n=3)$. $* \mathrm{P}<0.05$ compared to the control group. (B) RT-PCR analyses of mesoderm and cardiac markers Brachyury, Gata 4 and Nkx2.5 expression on EBs at D4 of differentiation in the presence of bFGF (1 ng/ml) or FGF8 (50 $\mathrm{ng} / \mathrm{ml})$ or FGF10 (100 ng/ml). PCR products separated on 1.5\% agarose gels are shown Gapdh was used as housekeeping gene and served to normalize the result.

undifferentiated ES cells expressed four members of Fgfr, i.e., Fgfr1, Fgfr2, Fgfr3 and Fgfr4, with high expression levels of Fgfr2 as compared to others (Fig. 1D). However, Ncam was absent in undifferentiated ES cells but expressed gradually during ES cell differentiation reaching a maximum by 9 days of differentiation (Fig. 1D).

\section{Screening of peptides}

Different molecules and growth factors from various origins have been used to discover new differentiation approaches for cardiomyocyte differentiation from pluripotent stem cells. Since large numbers of conditions can be examined in each screen, it is possible to efficiently discover optimized protocols that have advantages over more traditional cell culture protocols. Accumulating data in developmental studies have also suggested that growth factors such as FGF families play particularly important roles in the development and differentiation of the heart [32]. As fibroblast growth factor receptors Fgfr1-4 were expressed in our cell system during differentiation. Based on the results from initial screening experiments conducted for identifying the potential activities of bFGF, FGF8 and FGF10 to enhance in vitro cardiomyogenic differentiation of ES cells based, we decided to investigate this process closer by measuring the GFP signal intensity as well as the amount of Gata, Brachyury mRNA.

In order to determine the optimal time point for addition of growth factors and peptides, three different experimental protocols (EP) as illustrated in Figure 1A were carried out. In the presence of bFGF, FGF8 and FGF10, EP1 and EP3, data revealed significant GFP intensity as compared to control condition (absence of growth factors), whereas using EP2, no difference was observed (Fig. 2A), suggesting that the presence of important factors in a certain period during differentiation is crucial. A gene expression analysis under the treatment of all three FGFs revealed that Brachyury, an early mesodermal marker was expressed more under the treatment of bFGF than the other peptides. The expression of early cardiogenic markers Gata4 and Nkx2.5 were also analyzed. While Gata4 showed an increased expression under the treatment of all three FGFs compared with control, $N k x 2.5$ was detected only under the treatment of FGF10 (Fig. 2B). An estimation of the beating clusters on day 12 after FGF8 treatment revealed $78 \pm 12.6 \%$ and $65.5 \pm 9 \%$ in EP1 and EP3 respectively, while for FGF10 we measured $84 \pm 8 \%$ and $88.75 \pm 14.9 \%$ respectively.

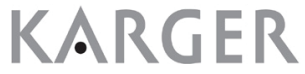




\section{Cellular Physiology Cell Physiol Biochem 2015;35:2437-2450 \begin{tabular}{l|l} 
DOI: 10.1159/000374044 & O 2015 S. Karger AG, Basel
\end{tabular} and Biochemistry Published online: April 24, $2015 \quad$ www.karger.com/cpb

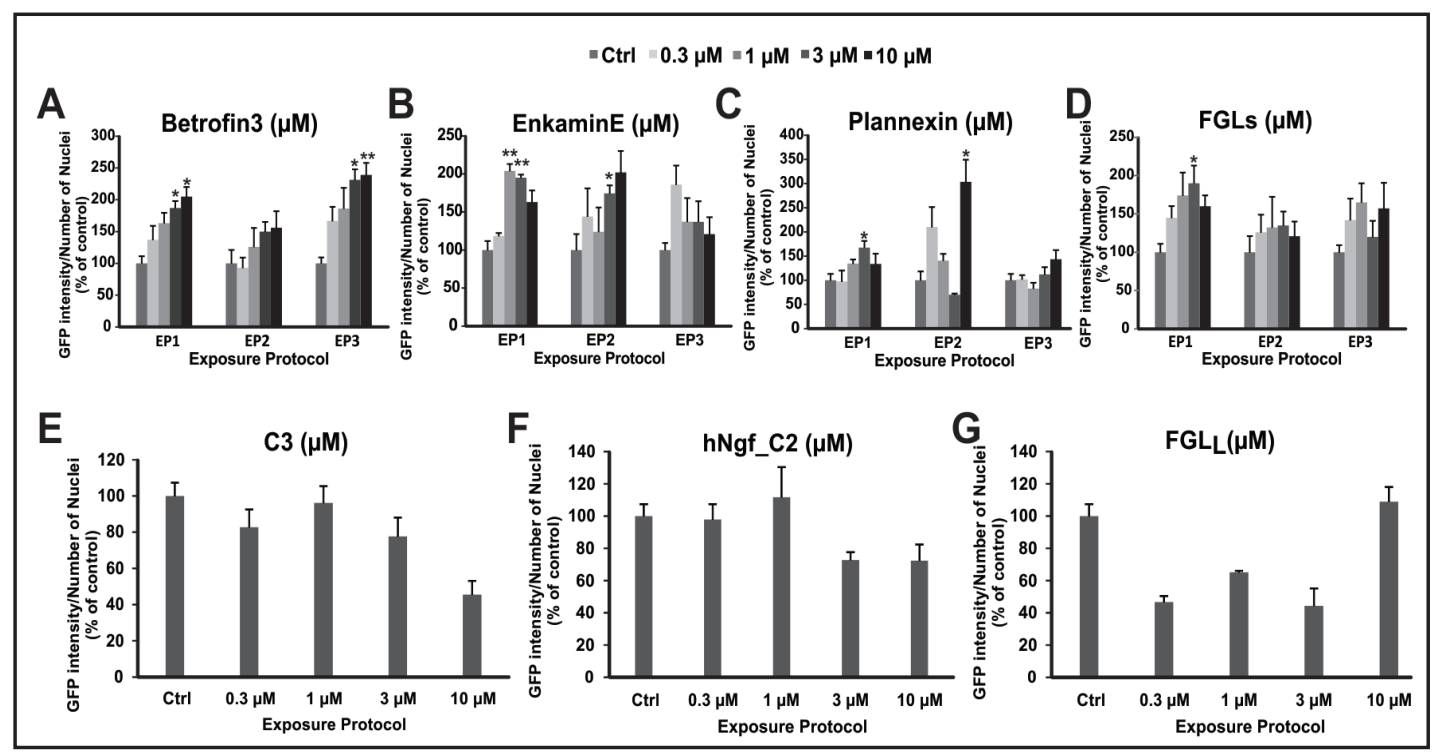

Fig. 3. Effect of small peptides derived from NCAM on cardiomyogenic differentiation of mouse ES cells. Percentage of EGFP positive cells (cardiomyocytes) derived from ES cells exposed to different concentrations of (A) Betrofin3, (B) EnkaminE, (C) Plannexin, (D) FGLs, (E) C3, (F) hNgf_C2 and (G) FGL. Peptides were applied as indicated in EP1, EP2 and EP3. EBs were dissociated and cells quantified at day 12 of differentiation. Results are reported as the mean $\pm S D(n=3)$. A significant increase $\left({ }^{*} P<0.05\right)$ of values, compared to vehicle controls, represent an effect on generation of cardiac cells.

To examine the effect of NCAM peptides and related proteins during cardiomyogenesis, different concentrations of Betrofin3, EnkaminE, Plannexin, hNgf-C2, C3, FGLs and FGL were added to the culture during differentiation using all three protocol described above. The results show that the continued presence of Betrofin3 in culture medium from day 0 to day 14 (EP1) and from day 3 to day 5 (EP3) significantly increased the intensity and number of GFP positive at both $3 \mu \mathrm{M}(87 \pm 11 \%$ - EP1, $131.4 \pm 16.6 \%$ - EP3) and $10 \mu \mathrm{M}$ (105 \pm 15\%- EP1, $37 \pm 19 \%$ - EP3) concentrations (Fig. 3A). Moreover, ES cells exposed to EnkaminE, Plannexin and FGLs even though showed a tendency for increased GFP intensity, did not promote cardiomyocyte differentiation using EP1. EnkaminE at concentration of 3 $\mu \mathrm{M}(74.5 \pm 10.37 \%)$ and Plannexin at $10 \mu \mathrm{M}(203.7 \pm 45.6 \%)$ were found to enhance the intensity of GFP in EP2. The peptides C3, hNgf_C2 and FGL however failed to significantly induce cardiomyogenesis in the ES cells at any tested concentrations when using EP1 (Fig. 3B). Taken together, the results suggest that these peptides may exert their effects early in the differentiation process when cells are at the stages of mesodermal and cardiovascular progenitor formation- i.e. from day 2 to day 5.

A comparative analysis of FGF8, FGF 10 and Betrofin3 in inducing cardiomyogenesis

To gain more insight in the effect of each peptide during cell differentiation, the expression of Brachyury (mesodermal marker) and MIc-2v (cardiac marker) were examined in EBs differentiated in the presence of FGF8, FGF10 and Betrofin3. The level of Brachyury expression was significantly higher on day 4 EBs differentiated in the presence of Betrofin3 as compared to FGF8-treated EBs, FGF10-treated EBs as well as to control EBs of the same differentiation day (Fig. 4A) generated with EP1. However, no significant difference was observed in the expression level of Mlc-2v in all peptide-treated conditions as compared to control (Fig. 4A). This result was partly confirmed by the FC analysis which showed a significant increase of EGFP-positive cells from $6.6 \%$ under control conditions to $8.3 \%$ and 9.9\% under FGF10- and Betrofin3-treatment (Fig. 4B). To determine the development of beating EBs over time in control and peptide-treated cultures, each well containing EBs was 


\section{Cellular Physiology Cell Physiol Biochem 2015;35:2437-2450 \begin{tabular}{ll|l} 
and Biochemistry & $\begin{array}{l}\text { DOI: 10.1159/000374044 } \\
\text { Published online: April 24, } 2015\end{array}$ & $\begin{array}{l}\text { ○ 2015 S. Karger AG, Basel } \\
\text { www.karger.com/cpb }\end{array}$ \\
\hline
\end{tabular}}

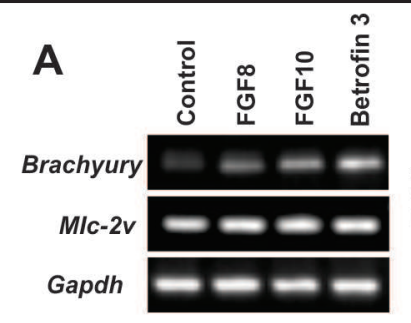

\section{B Control}
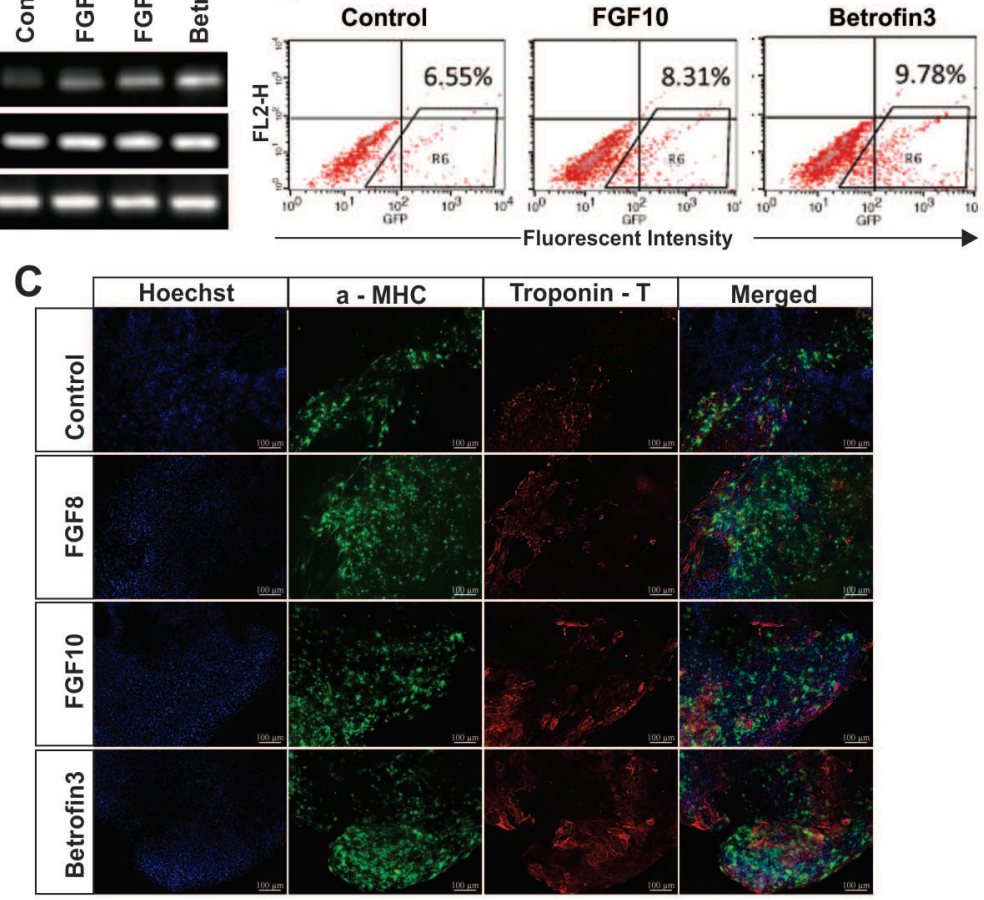

Fig. 4. Comparaison effect Betrofin3 vs FGF8 and FGF10 on cardiomyogenic differentiation of mouse ES cells. (A) RT-PCR analyses of mesodermal (Brachyury) cardiac-specific (Mlc-2v) markers on EBs at day 4 and 12 of ES cell differentiation, respectively. Note that FGF8, FGF10 and Betrofin3 enhance expression of Brachyury without any effect on late expressed Mlc-2v. (B) Representative results of flow cytometric analysis of ES cell-derived CMs differentiated under FGF10 and Betrofin3 treatment at day 12 of differentiation. Note the increase of EGFP positive cells fraction generated under FGF10 and Betrofin3. (C) Immunofluorescent staining of cardiomyocyte specific proteins in the EBs on the $12^{\text {th }}$ days of differentiation following treatment as indicated in EP1. Cardiomyocytes in EBs were examined for $a$-MHC (Green panels) and TnT (Red panels). Hoechst 33342 was used to stain nuclei (blue). Merged images are indicated. Scale bars: $100 \mu \mathrm{m}$.

examined daily from day 7 to day 15 of differentiation for the appearance of spontaneously contracting EBs. The percentage of beating EBs increased gradually from day 8 to day 12 in all conditions. No significant difference in the number of beating EBs was observed between control and peptide-treated condition (data not shown).

To examine the representation of cardiovascular lineages in EB differentiation under peptide treatment using EP1, we performed immunofluorescence staining on day 12 EB outgrowths by using antibodies against cardiac sarcomeric $\alpha$-MHC and Troponin-T (Fig. 4C). The results show that abundant cardiomyocyte populations were observed in FGF8FG10- and Betrofin3-treated EBs compared to control confirming, in some extent, the above mentioned FC results.

\section{Electrophysiological evaluation of Betrofin3-treated beating EBs - Hormonal regulation}

To test whether gain of gene expression actually reflects cardiomyocytes with distinct functional properties, we performed sharp electrode measurements to record spontaneous action potentials (AP) and to confirm the cardiomyogenic differentiation of treated cells at the functional level. All EBs generated with all three protocols (EP1, EP2 and EP3) described above displayed spontaneous AP synchronous to their contractions (Fig. 5A, above panel). Basic AP parameters [Frequency, AP Amplitude (APA), Action potential duration at $50 \%$ and $90 \%$ repolarization (APD50 and APD90)] of EBs generated in the absence (control) 


\section{Cellular Physiology Cell Physiol Biochem 2015;35:2437-2450

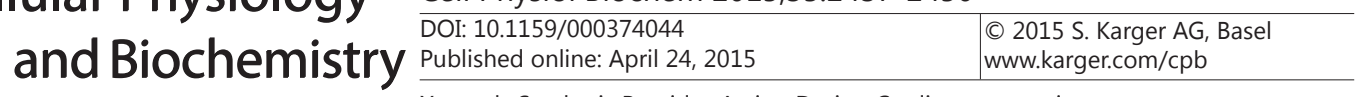

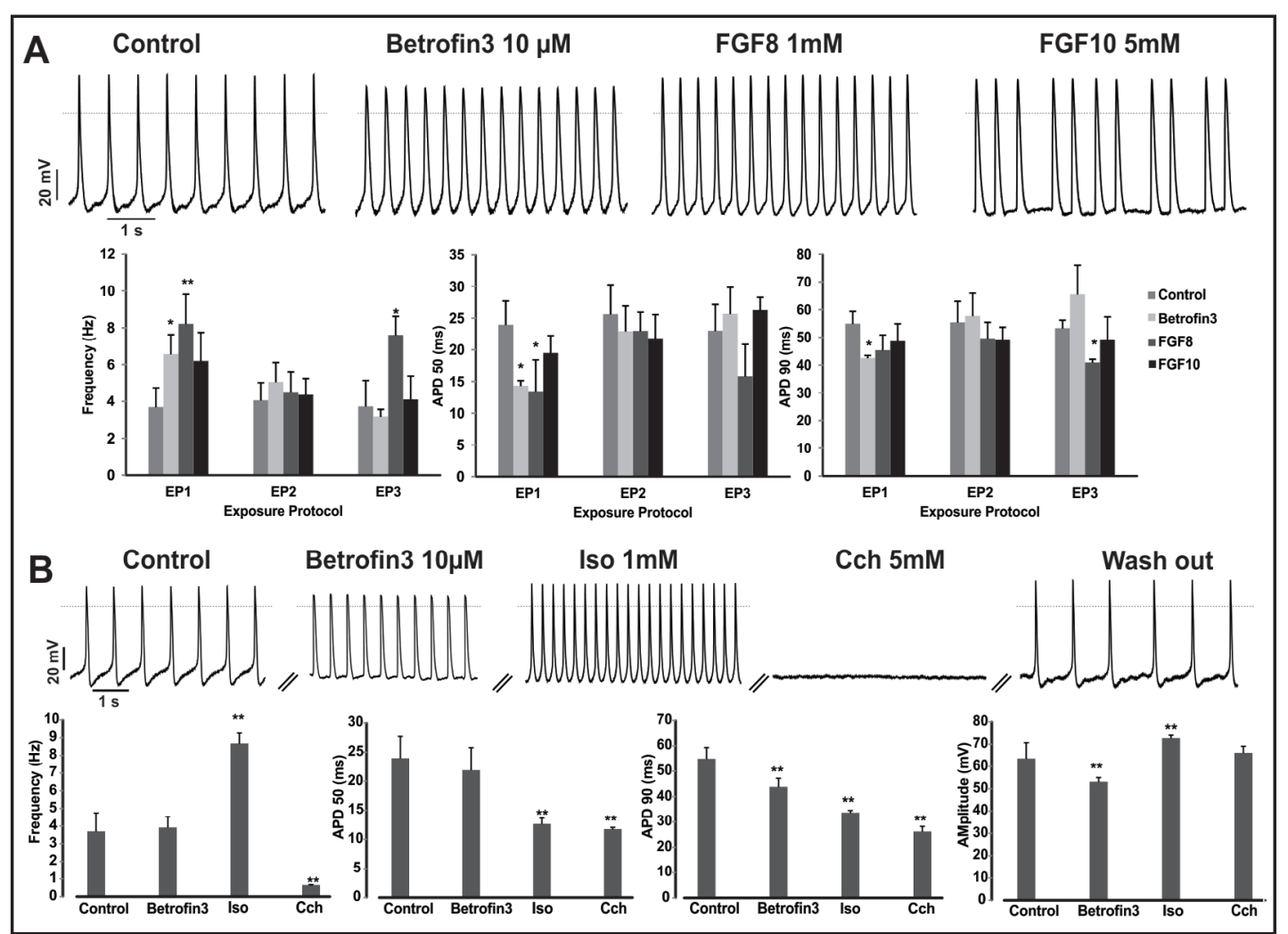

Fig. 5. Electrophysiological evaluation of beating EBs generated under Betrofin3-treatment. (A) Representative AP recordings from spontaneously contracting EBs on the $14^{\text {th }}$ of differentiation after 12 days Betrofin3-, FGF8- and FGF10-treatment compared to AP of control group. Statistical analysis (below panel) of different AP parameters is displayed. (B) The panel represents the action potential traces of control EBs

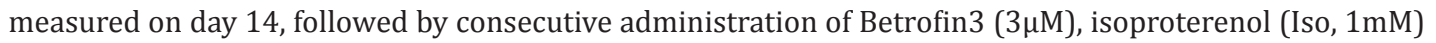
and carbachol (CCh, $5 \mathrm{mM}$ ) followed by a wash out. Statistical analysis (below panel) of the effect of Betrofin3 $(3 \mu \mathrm{M})$, isoproterenol (Iso, $1 \mathrm{mM})$ and carbachol (CCh, $5 \mathrm{mM}$ ) on AP parameters is presented. The dotted lines indicate the zero current level.

and presence of the peptides at day 14 of differentiation using EP1, EP2 and EP3 protocols, respectively, are indicated in Figure 5A. It shows that, when using EP1 both peptidesBetrofin3 and FGF8 induced significant changes in beating frequency of EBs as compared to control EBs ( $8.22 \pm 1.5$ vs $3.7 \pm 1.0 \mathrm{~Hz}$ and $6.6 \pm 1.1$ vs $3.7 \pm 1.0 \mathrm{~Hz}(\mathrm{P}<0.05)$, respectively), as well as to EBs derived with EP2 protocol under indicated peptides-treatment $(\mathrm{P}<0.05)$. Similarly, EBs generated with EP3 protocol under FGF8-treatment showed significantly increased beating activity as compared to control condition EBs $(7.6 \pm 1.0$ vs $4.0 \pm 1.0 \mathrm{~Hz}),(\mathrm{P}<0.05)$. Higher firing rates were accompanied by shorter APD50 and APD90 values (Fig. $5 \mathrm{~A}$ ).

Moreover, as a critical determinant of normal cardiomyocyte function is the intact and normal response to hormones and transmitters of the central nervous system, we also assessed the pharmacological response of EBs generated with EP1 and examined their acute reaction to Betrofin3 and other peptides tested to see which one revealed the most striking effect on AP parameters. In all spontaneously beating EBs generated under control and Betrofin-treated conditions, exposure to Betrofin 3 slightly increased the beating frequency $(4.0 \pm 0.6$ vs $3.6 \pm 1.0 \mathrm{~Hz})(\mathrm{P}>0.05)$, whereas subsequent application of $\beta$-adrenergic agonist, Isoprenaline (Iso) $(1 \mu \mathrm{M})$ and acetylcholine analog Carbachol (CCh) $(1 \mu \mathrm{M})$, induced a significant positive $(128 \%$ increase, $\mathrm{P}<0.05)$ and negative $(75 \%$ decrease, $\mathrm{P}<0.05)$ chronotropic effect on AP frequency, respectively (Fig. 5B). The beating activity of most EBs tested partially returned to control values after washout of Iso and CCh. In addition, acute 


\section{Cellular Physiology Cell Physiol Biochem 2015;35:2437-2450 \begin{tabular}{ll|l} 
and Biochemistry & $\begin{array}{l}\text { DOI: 10.1159/000374044 } \\
\text { Published online: April 24, } 2015\end{array}$ & $\begin{array}{l}\text { ○ 2015 S. Karger AG, Basel } \\
\text { www.karger.com/cpb }\end{array}$ \\
\hline
\end{tabular} Xu et al.: Synthetic Peptides Action During Cardiomyogenesis}

A

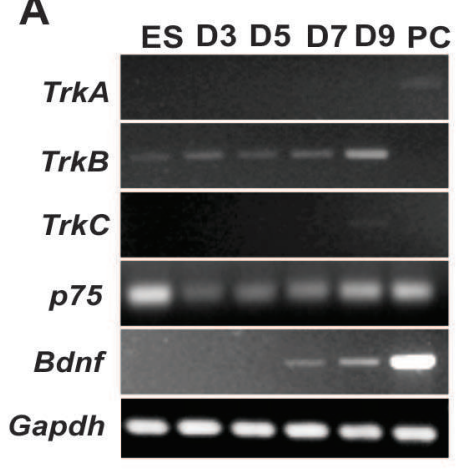

B

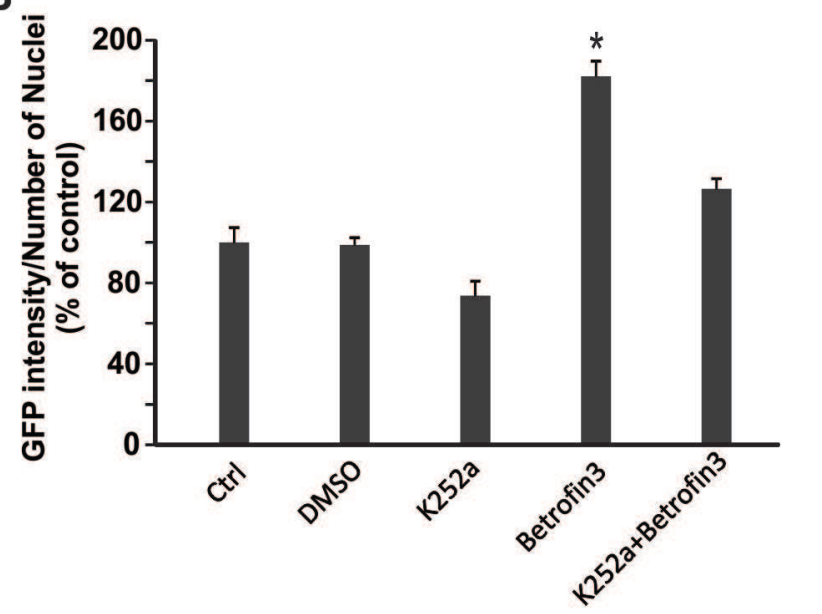

Fig. 6. Expression of $B d n f$, TrkA, TrkB, TrkC and $p 75$ in ES cells during differentiation towards cardiomyocytes. (A) RT-PCR analysis of $\operatorname{Trk} A, \operatorname{TrkB}, \operatorname{TrkC}, p 75$ and $B d n f$ gene expression level in undifferentiated (ES) and differentiated cells at day 3, 5, 7 and 9 of differentiation as well as in adult mouse cardiomyocytes (used as positive control, PC). Gapdh expression levels were used as an internal control. (B) Effect of K-252a followed by Betrofin3 treatment on cardiomyogenic differentiation of mouse ES cells. The bar graph of these results indicates that Betrofin3 significant increase in the number of EGFP positive cells (cardiomyocytes) in ES cells during differentiation and that K252a inhibited the ability of these cells to efficiently differentiate into cardiomyocyte. The data were obtained from similar results of at least three independent experiments. Results are expressed as percent of control values and presented as mean \pm SE. *; $\mathrm{P}<0.05$ vs. control.

application of Betrofin3 also significanlty induced changes in AP amplitude (63.6 \pm 7.0 vs $53.1 \pm 1.8 \mathrm{mV}, \mathrm{P}<0.05$ ), and APD90 ( $0.7 \pm 0.1$ fold change, $\mathrm{P}<0.05$ ) of the EBs (Fig $5 \mathrm{~B}$, below panel) without affecting the beating frequency. Inhibition of the Iso effect by CCh during the same measurements indicated the presence of coupled $\beta$-adrenergic and muscarinic signaling cascades in cardiomyocytes.

\section{Betrofin3 induced cardiomyogenesis via TrkB signaling}

To understand the potential mechanism underlying the cardiomyogenic effect of Betrofin3 (a BDNF mimetic peptide) during ES cells differentiation, we first analyzed the expression of $B d n f$ and its receptor family $\operatorname{Trk} A, \operatorname{TrkB}, \operatorname{Trk} C$ and $p 75$ during differentiation using EP1 protocol. Results indicate that TrkA is not expressed at any examined stage of differentiation while TrkC is found only weakly expressed or absent in EBs at day 9 of differentiation. The expression of $\operatorname{Trk} B$ was found to increase steadily during differentiation whereas $B d n f$ expression was first detected at about day 5 of differentiation. However, P75 expression was down-regulated during differentiation (Fig. 6A).

In order to confirm that Betrofin3 acted through the BDNF/TrkB signaling, we used the EP1 protocol in the presence of K252a, a selective inhibitor of TrkB at appropriate concentration determined preliminary. The results revealed that $30 \mathrm{nM}$ of K252a markedly decreased the intensity of EGFP positive cells (Fig. 6B). In addition, the number of cardiomyocytes was significantly reduced in the presence of K252a as compared to control, but significantly increased in Betrofin3-treated condition as reported in Figure 4B. The application of K252a followed by Betrofin3 inhibit the differentiation of ES cell-derived cardiomyocytes as compared with Betrofin3 treatment (Fig. 6B). These results suggest that Betrofin3 enhances the differentiation of ES cell-derived cardiomyocytes and at least in part that a TrkB receptor blockade by K252a may negatively regulate the differentiation process of the ES cells into cardiomyocytes. Consistent with our finding, Bdnf starts to be expressed around E17.5 during mouse development and peaks at around postnatal day 2 as well as 


\section{Cellular Physiology Cell Physiol Biochem 2015;35:2437-2450 \\ \begin{tabular}{ll|l} 
DOI: 10.1159/000374044 & $\begin{array}{l}\text { C 2015 S. Karger AG, Basel } \\
\text { www.karger.com/cpb }\end{array}$ \\
\hline
\end{tabular}}

$T r k B$, whose expression begins about one day later and reaches the peak level in the neonatal and adult heart [27, 33, 34]. Moreover, it was shown that Bdnf-deficient mice die in the early postnatal stage, which may suggest at least in part that BDNF has important functions in cardiac development and activity in addition to its neurotrophic effects [33].

In conclusion, these data indicated that some peptides such as Betrofin3, when present in differentiation medium may at least in part regulate the differentiation process of ES cells into cardiomyocytes and may influence the functional properties of derived cardiomyocytes.

\section{Discussion}

The reproducible differentiation of pluripotent stem cells observed in culture using the EB formation approach has been exploited to identify factors capable of influencing cardiomyogenic induction. In this work, we have tested the idea of directing cardiomyogenic differentiation of mouse ES cells with small peptides derived from NCAM or related peptides. The approach is focused on a subset of factors shown to be critically involved in cell proliferation, migration and differentiation of neural progenitors $[35,36]$. The neurotrophin family of growth factors such as nerve growth factor (NGF), brain-derived neurotrophic factor (BDNF), neurotrophin (NT)-3, and NT-4/5 plays pivotal roles in the development of the nervous system. Most of theirs receptors have been shown to be expressed in heart during development and to be associated with muscle regeneration and marks adult myogenic cell committed differentiation [27, 37-40]. In this study, we have investigated the effect of synthetic peptides named Betrofin3, FGLs, FGLL, hNgf_C2, EnkaminE, Plannexin and C3, all derived from BDNF, FGF, NCAM or NCAM related proteins, on cardiac differentiation. The results presented in this work suggest a new role for some small peptides during ES cell differentiation toward cardiomyocytes, which may boost the perspectives of using peptides as probes to dissect pathways involved in cardiac differentiation with regenerative potential for heart injury.

The FGF signalling has been implicated in the process of heart development as well as differentiation and cardiomyogenesis [41]. Moreover disruption of FGF signalling leads to severe defects in heart formation $[11,42]$. Therefore, we first demonstrate that FGF receptors (Fgfr1-4) and Ncam are expressed in our ES cells system. Growth factors- bFGF, FGF8 and FGF10 which are known as regulators of cardiomyogenesis by activating their corresponding receptors $[6,13,43,44]$, were used as positive control to assess the efficiency of the peptides in cardiac differentiation. The continuous presence of bFGF, FGF8 and FGF10 in culture medium during the differentiation process enhances the proportion of ES cellderived cardiomyocytes as demonstrated by the significant increase of EGFP positive cells and cardiac specific genes and proteins. This finding confirms that FGF receptors mediate cardiomyocytes development in EBs, at least in part by activating NKx2.5 expression. In fact, differentiating EBs from murine $\mathrm{Fgfr}^{\wedge}$ ES cells had failed to form beating cardiomyocyte foci and do not express cardiac markers [11].

In addition, our results revealed that of the seven peptides screened, four (Betrofin3, $\mathrm{FGL}_{\mathrm{L}}$, EnkaminE and Plannexin) were found to enhance EGFP expression in the ES cells carrying a cardiac-specific reporter transgene encoding EGFP in a concentration-and timedependent manner as described in our results. Among those that enhance EGFP intensity, Betrofin3 was the most prominent one with significant effect as compared to others. Moreover, a comparative analysis between Betrofin3, FGF8 and FGF10 indicates an approximate 1.5fold increase in the relative number of cardiomyocytes following Betrofin3 treatment, suggesting its strongest cardiogenic activity. Structurally, Betrofin3 is a mimetic peptide which was derived from the BDNF sequence. BDNF is a neurotrophin, which modulates the survival and differentiation of peripheral and central neurons expressing the tyrosine kinase receptor (TrkB) [17]. Although it is associated with the nervous system, BDNF is also shown to mediate angiogenesis [45]. It plays an important role in the formation, development and maintenance of the vascular system. A previous study conducted on intramyocardial 


\section{Cellular Physiology Cell Physiol Biochem 2015;35:2437-2450 \begin{tabular}{ll|l} 
and Biochemistry $10.1159 / 000374044$ & \multicolumn{1}{c}{ Published online: April 24, 2015} & $\begin{array}{l}\text { C } 2015 \text { S. Karger AG, Basel } \\
\text { www.karger.com/cpb }\end{array}$ \\
\cline { 2 - 3 } &
\end{tabular}}

arteries and capillaries demonstrates the importance of BDNF in angiogenesis via the TrkB receptor expressing endothelial cells [46]. Albeit the angiogenic function of BDNF has been well documented in normal and disease patients [47], its role in cardiomyogenesis has rarely been demonstrated. It has been shown to be expressed in embryonic heart [48]. Donovan et al [27] demonstrated that BDNF is a cardiac endothelial cell survival factor operating through activation of the endogenous Tropomyosin related kinase B (TrkB) receptors. It binds with the receptors TrkB and p75 neurotrophin receptor (p75NTR) [49], subsequently leading to activation of various intracellular signalling cascades including phosphatidylinositol 3-kinase (PI3-K)/Akt, Ras/mitogen activated protein kinase (APK) and phospholipase $\mathrm{C} \gamma$ (PLC $\gamma$ ) that are involved in early cardiac development [46-48]. The expression pattern of TrkB and $p 75 N T R$ during cardiac differentiation in our study and the marked decrease of EGFP positive cells generated in the presence of K252a, an inhibitor of TrkB, revealed that Betrofin3 might at least in part function through activation of TrkB and p75NTR or the complex BDNF-TrKB-FL-PI3K/Akt pathway during cardiac differentiation as previously suggested for cardiac microvascular endothelial cells [46].

In addition, the changes in APs recorded during acute-application of Betrofin3 may indicate modulation of BDNF-TrKB signalling pathways. In fact, modulation of ion channels by protein kinases/phosphatases is a well-known mechanism by which the excitability of spontaneous beating cells such as cardiac and neurons is altered. It happens for many classes of ion channels, including $\mathrm{Na}^{+}, \mathrm{Ca}^{2+}$ and $\mathrm{K}^{+}$channels which are largely involved in generating and shaping APs. BDNF has been shown to cause direct opening of $\mathrm{Na}^{+}$channel (via an as-yet unknown coupling mechanism), which in turn results in the influx of $\mathrm{Na}^{+}$ions and activation of $\mathrm{Ca}^{2+}$ current in neurons [50]. This phenomenon could at least in part also occur in cardiac cells. Thus, if this is the case, BDNF would emerge as a potent cardio modulator. However, future studies are needed to elucidate the cellular mechanism and signalling pathways by which BDNF may induce modulation of ion channels in cardiac cells. The elucidation of these important questions will add exciting new insights to our understanding of the role of small peptides derived from NCAM and related proteins to possess a cardiogenic potency which needs to be further evaluated with high-throughput validation techniques as well as supportive in vivo studies.

In conclusion, our findings represent a stepwise advancement over the role of small peptides during cell differentiation and may eventually lead to an understanding of the role of NCAM and related proteins in clinical syndromes and heart diseases.

\section{Acknowledgements}

We thank Susan Rohani, Cornelia Böttinger and Annette Köster for their technical assistance as well as Suzanne Wood and Elke Lieske for the secretarial assistance. This study was funded by grant from EU FP7 project (STEMCAM, PIAP-GA-2009-251186).

\section{Disclosure Statement}

None declared.

\section{References}

1 World Health Organization (WHO): Global status report on noncommunicable diseases 2010. WHO 2011. Available at http://www.who.int/chp/ncd_global_status_report/en/.

2 Segers VF, Lee RT: Stem-cell therapy for cardiac disease. Nature 2008;451:937-942.

3 Senyo SE, Lee RT, Kuhn B: Cardiac regeneration based on mechanisms of cardiomyocyte proliferation and differentiation. Stem Cell Res 2014;13:532-541.

4 Nguemo F, Semmler J, Reppel M, Hescheler J: Modulation of l-type calcium current by intracellular magnesium in differentiating cardiomyocytes derived from induced pluripotent stem cells. Stem Cells Dev 2014;23:1316-1327. 


\section{Cellular Physiology Cell Physiol Biochem 2015;35:2437-2450 \begin{tabular}{l|l}
\hline DOI: 10.1159/000374044 & (c) 2015 S. Karger AG, Basel
\end{tabular} and Biochemistry Published online: April 24, $2015 \quad$ www.karger.com/cpb}

Xu et al:: Synthetic Peptides Action During Cardiomyogenesis

5 Gupta MK, Illich DJ, Gaarz A, Matzkies M, Nguemo F, Pfannkuche K, Liang H, Classen S, Reppel M, Schultze JL, Hescheler J, Saric T: Global transcriptional profiles of beating clusters derived from human induced pluripotent stem cells and embryonic stem cells are highly similar. BMC Dev Biol 2010;10:98.

6 Kawai T, Takahashi T, Esaki M, Ushikoshi H, Nagano S, Fujiwara H, Kosai K: Efficient cardiomyogenic differentiation of embryonic stem cell by fibroblast growth factor 2 and bone morphogenetic protein 2 . Circ J 2004;68:691-702.

7 Wei H, Juhasz O, Li J, Tarasova YS, Boheler KR: Embryonic stem cells and cardiomyocyte differentiation: Phenotypic and molecular analyses. J Cell Mol Med 2005;9:804-817.

8 Liau B, Zhang D, Bursac N: Functional cardiac tissue engineering. Regen Med 2012;7:187-206.

9 Perrier AL, Tabar V, Barberi T, Rubio ME, Bruses J, Topf N, Harrison NL, Studer L: Derivation of midbrain dopamine neurons from human embryonic stem cells. Proc Natl Acad Sci U S A 2004;101:12543-12548.

10 Behfar A, Zingman LV, Hodgson DM, Rauzier JM, Kane GC, Terzic A, Puceat M: Stem cell differentiation requires a paracrine pathway in the heart. FASEB J 2002;16:1558-1566.

11 Dell'Era P, Ronca R, Coco L, Nicoli S, Metra M, Presta M: Fibroblast growth factor receptor-1 is essential for in vitro cardiomyocyte development. Circ Res 2003;93:414-420.

12 Wobus AM, Kaomei G, Shan J, Wellner MC, Rohwedel J, Ji G, Fleischmann B, Katus HA, Hescheler J, Franz WM: Retinoic acid accelerates embryonic stem cell-derived cardiac differentiation and enhances development of ventricular cardiomyocytes. J Mol Cell Cardiol 1997;29:1525-1539.

13 Chan SS, Li HJ, Hsueh YC, Lee DS, Chen JH, Hwang SM, Chen CY, Shih E, Hsieh PC: Fibroblast growth factor-10 promotes cardiomyocyte differentiation from embryonic and induced pluripotent stem cells. PLoS One 2010;5:e14414.

14 Coumoul X, Deng CX: Roles of fgf receptors in mammalian development and congenital diseases. Birth Defects Res C Embryo Today 2003;69:286-304.

15 Williams EJ, Furness J, Walsh FS, Doherty P: Activation of the fgf receptor underlies neurite outgrowth stimulated by 11, n-cam, and n-cadherin. Neuron 1994;13:583-594.

16 Ballinger MD, Shyamala V, Forrest LD, Deuter-Reinhard M, Doyle LV, Wang JX, Panganiban-Lustan L, Stratton JR, Apell G, Winter JA, Doyle MV, Rosenberg S, Kavanaugh WM: Semirational design of a potent, artificial agonist of fibroblast growth factor receptors. Nat Biotechnol 1999;17:1199-1204.

17 Fobian K, Owczarek S, Budtz C, Bock E, Berezin V, Pedersen MV: Peptides derived from the solvent-exposed loops 3 and 4 of bdnf bind trkb and p75(ntr) receptors and stimulate neurite outgrowth and survival. J Neurosci Res 2010;88:1170-1181.

18 Thiery JP, Duband JL, Rutishauser U, Edelman GM: Cell-adhesion molecules in early chicken embryogenesis. Proc Natl Acad Sci U S A 1982;79:6737-6741.

19 Watanabe M, Timm M, Fallahnajmabadi H: Cardiac expression of polysialylated ncam in the chickenembryo - correlation with the ventricular conduction system. Dev Dyn 1992;194:128-141.

20 Byeon MK, Sugi Y, Markwald RR, Hoffman S: Ncam polypeptides in heart development - association with z-disks of forms that contain the muscle-specific domain. J Cell Biol 1995;128:209-221.

21 Burroughs CL, Watanabe M, Morse DE: Distribution of the neural cell-adhesion molecule (ncam) during heart development. J Mol Cell Cardiol 1991;23:1411-1422.

22 Reyes AA, Small SJ, Akeson R: At least 27 alternatively spliced forms of the neural cell-adhesion molecule messenger-rna are expressed during rat-heart development. Mol Cell Biol 1991;11:1654-1661.

23 Okagawa H, Nakagawa M, Simada M: Immunolocalization of n-cam in the heart of the early developing rat embryo. Anat Rec 1995;243:261-271.

24 Hansen SM, Kohler LB, Li S, Kiselyov V, Christensen C, Owczarek S, Bock E, Berezin V: Ncam-derived peptides function as agonists for the fibroblast growth factor receptor. J Neurochem 2008;106:2030-2041.

25 Huang EJ, Reichardt LF: Trk receptors: Roles in neuronal signal transduction. Ann Rev Biochem 2003;72:609-642.

26 Kermani P, Hempstead B: Brain-derived neurotrophic factor: A newly described mediator of angiogenesis. Trends Cardiovasc Med 2007;17:140-143.

27 Donovan MJ, Lin MI, Wiegn P, Ringstedt T, Kraemer R, Hahn R, Wang S, Ibanez CF, Rafii S, Hempstead BL: Brain derived neurotrophic factor is an endothelial cell survival factor required for intramyocardial vessel stabilization. Development 2000;127:4531-4540. 


\section{Cellular Physiology Cell Physiol Biochem 2015;35:2437-2450 \begin{tabular}{ll|l} 
and Biochemistry & $\begin{array}{l}\text { DOI: 10.1159/000374044 } \\
\text { Published online: April 24, } 2015\end{array}$ & $\begin{array}{l}\text { ○ 2015 S. Karger AG, Basel } \\
\text { www.karger.com/cpb }\end{array}$ \\
\hline
\end{tabular}}

Xu et al.: Synthetic Peptides Action During Cardiomyogenesis

28 Kolossov E, Fleischmann BK, Liu Q, Bloch W, Viatchenko-Karpinski S, Manzke O, Ji GJ, Bohlen H, Addicks K, Hescheler J: Functional characteristics of es cell-derived cardiac precursor cells identified by tissue-specific expression of the green fluorescent protein. J Cell Biol 1998;143:2045-2056.

29 Kolossov E, Lu Z, Drobinskaya I, Gassanov N, Duan Y, Sauer H, Manzke O, Bloch W, Bohlen H, Hescheler J, Fleischmann BK: Identification and characterization of embryonic stem cell-derived pacemaker and atrial cardiomyocytes. FASEB J 2005;19:577-579.

30 Hao J, Ao A, Zhou L, Murphy CK, Frist AY, Keel JJ, Thorne CA, Kim K, Lee E, Hong CC: Selective small molecule targeting beta-catenin function discovered by in vivo chemical genetic screen. Cell Rep 2013;4:898-904.

31 Kattman SJ, Huber TL, Keller GM: Multipotent flk-1+ cardiovascular progenitor cells give rise to the cardiomyocyte, endothelial, and vascular smooth muscle lineages. Dev Cell 2006;11:723-732.

32 Sarkar P, Rao BM: Molecular aspects of cardiac differentiation in embryonic stem cells. Crit Rev Biomed Eng 2009;37:283-320.

33 Ernfors P, Lee KF, Jaenisch R: Mice lacking brain-derived neurotrophic factor develop with sensory deficits. Nature 1994;368:147-150.

34 Baydyuk M, Xu B: Bdnf signaling and survival of striatal neurons. Front Cell Neurosci 2014;8:254.

35 Glaser T, Brose C, Franceschini I, Hamann K, Smorodchenko A, Zipp F, Dubois-Dalcq M, Brustle O: Neural cell adhesion molecule polysialylation enhances the sensitivity of embryonic stem cell-derived neural precursors to migration guidance cues. Stem Cells 2007;25:3016-3025.

36 Amoureux MC, Cunningham BA, Edelman GM, Crossin KL: N-cam binding inhibits the proliferation of hippocampal progenitor cells and promotes their differentiation to a neuronal phenotype. J Neurosci 2000;20:3631-3640.

37 Wharton J, Gordon L, Walsh FS, Flanigan TP, Moore SE, Polak JM: Neural cell adhesion molecule (n-cam) expression during cardiac development in the rat. Brain Res 1989;483:170-176.

38 Nagao K, Ono K, Iwanaga Y, Tamaki Y, Kojima Y, Horie T, Nishi H, Kinoshita M, Kuwabara Y, Hasegawa K, Kita T, Kimura T: Neural cell adhesion molecule is a cardioprotective factor up-regulated by metabolic stress. J Mol Cell Cardiol 2010;48:1157-1168.

39 Lin MI, Das I, Schwartz GM, Tsoulfas P, Mikawa T, Hempstead BL: Trk c receptor signaling regulates cardiac myocyte proliferation during early heart development in vivo. Dev Biol 2000;226:180-191.

40 Kraemer R, Baker PJ, Kent KC, Ye Y, Han JJ, Tejada R, Silane M, Upmacis R, Deeb R, Chen Y, Levine DM, Hempstead B: Decreased neurotrophin trkb receptor expression reduces lesion size in the apolipoprotein e-null mutant mouse. Circulation 2005;112:3644-3653.

41 Perino MG, Yamanaka S, Li J, Wobus AM, Boheler KR: Cardiomyogenic stem and progenitor cell plasticity and the dissection of cardiopoiesis. J Mol Cell Cardiol 2008;45:475-494.

42 Zhang J, Liu J, Liu L, McKeehan WL, Wang F: The fibroblast growth factor signaling axis controls cardiac stem cell differentiation through regulating autophagy. Autophagy 2012;8:690-691.

43 Park EJ, Ogden LA, Talbot A, Evans S, Cai CL, Black BL, Frank DU, Moon AM: Required, tissue-specific roles for fgf8 in outflow tract formation and remodeling. Development 2006;133:2419-2433.

44 Powers CJ, McLeskey SW, Wellstein A: Fibroblast growth factors, their receptors and signaling. Endocr Relat Cancer 2000;7:165-197.

45 Scarisbrick IA, Jones EG, Isackson PJ: Coexpression of mrnas for ngf, bdnf, and nt-3 in the cardiovascular system of the pre- and postnatal rat. J Neurosci 1993;13:875-893.

46 Cao L, Zhang L, Chen S, Yuan Z, Liu S, Shen X, Zheng X, Qi X, Lee KK, Chan JY, Cai D: Bdnf-mediated migration of cardiac microvascular endothelial cells is impaired during ageing. J Cell Mol Med 2012;16:3105-3115.

47 Anastasia A, Deinhardt K, Wang S, Martin L, Nichol D, Irmady K, Trinh J, Parada L, Rafii S, Hempstead BL, Kermani P: Trkb signaling in pericytes is required for cardiac microvessel stabilization. PLoS One 2014;9:e87406.

48 Wagner M, Siddiqui MA: Signal transduction in early heart development (i): Cardiogenic induction and heart tube formation. Exp Biology Med 2007;232:852-865.

49 Kermani P, Rafii D, Jin DK, Whitlock P, Schaffer W, Chiang A, Vincent L, Friedrich M, Shido K, Hackett NR, Crystal RG, Rafii S, Hempstead BL: Neurotrophins promote revascularization by local recruitment of trkb+ endothelial cells and systemic mobilization of hematopoietic progenitors. J Clin Invest 2005;115:653-663.

50 Rose CR, Blum R, Kafitz KW, Kovalchuk Y, Konnerth A: From modulator to mediator: Rapid effects of bdnf on ion channels. Bio Essays 2004;26:1185-1194. 